\title{
MOLLUSC ASSEMBLAGES OF AN ANCIENT LAKE IN RÓŻYNY NEAR SKOWARCZ (ŻUŁAWY WIŚLANE, N POLAND)
}

\author{
Witold PAWEŁ AlEXANDROWICZ
}

\begin{abstract}
Chair of Stratigraphy and Regional Geology, Academy of Mining and Metallurgy, Mickiewicza 30, 30-059 Kraków, Poland

ABSTRACT: Rich mollusc assemblages have been found in Late Glacial and Holocene deposits filling an ancient lake in Różyny near Skowarcz. The fauna is associated mainly with lacustrine chalk or calcareous gyttja, and sporadically with peat. The succession of mollusc communities was studied in detail at seven logs, and several types of such communities can be distinguished. They reflect changes of climate, differentiation of habitats as well as the evolution of the lake.
\end{abstract}

KEY WORDS: mollusc assemblages, Holocene, Late Glacial, ancient lake, community succession, environmental changes

\section{INTRODUCTION}

Mollusc-bearing deposits of Late Glacial and Early Holocene age in Northern Poland are developed mainly as lacustrine chalk or calcareous gyttja. They fill up lakes and other types of small water bodies formed during the final stage of Vistulian. Evolution of mollusc assemblages indicates changes of the climate. Different types of mollusc communities and succession of the fauna occur in lake deposits representing the time span since the Late Glacial till the Post-glacial climatic optimum (Atlantic Phase). They

\section{MATERIAL AND METHODS}

The described site is located near the village Różyny, in the peripheral, south-western part of Żuławy Wiślane, about $30 \mathrm{~km}$ south of Gdańsk (Fig. 1). The ancient depression and lake are filled with lacustrine chalk, calcareous gyttja and peat underlain by fluvioglacial sand and gravel. The geological structure and the distribution of particular types of sediments were recognised in about one hundred trenches and bore-holes, described in detail by MATUSZEWSKI (1991). Malacological studies were carried out on were described from many localities found in whole Northern Poland. In some of them the occurrence of snails and bivalves was noted (BRODNIEWICZ 1979, S. W. ALEXANDROWICZ 1980, 1988, 1989, 1991, 1995, S. W. ALEXANDROWICZ \& TCHÓRZEWSKA 1981, S. W. AleXANDROWICZ \& NOWACZYK 1982, W. P. ALEXANDROWICZ 1999, WOJCIECHOWSKI 2000 and others). The present study is a contribution to scientific project No 11.11.140.917, sponsored by the Academy of Mining and Metallurgy in Cracow.

seven logs (Sk-I - Sk-VII) and 41 samples (Fig. 1). The whole material studied comprises near 25,000 specimens representing 54 mollusc taxa, including 24 species of terrestrial and 21 species of aquatic snails, as well as 9 bivalves (Tables 1,2). Standard methods of malacological analysis described by LO EK (1964) and S. W. AleXANDrowicZ (1987, 1999) have been used. All taxa belong to ecological groups representing two comprehensive categories: land snails and water molluscs. Ecological requirements of particular 
species were described by PIECHOCKI (1979), RIEDEL (1988) and Dyduch-FALNiOWSKA \& PIECHOGKI (1993).

\section{LOGS DESCRIPTION AND MALACOFAUNA}

Lacustrine chalk intercalated with calcareous gyttja and peat were distinguished in the profile Sk-I. The thickness of the lake deposits is about $7 \mathrm{~m}$ (Fig. 2). Six samples containing rich mollusc fauna were collected from this $\log$ (Fig. 2). The number of species varied from 10 to 25 per sample, whereas the number of specimens ranged from 70 to 1,674 . Two mollusc communities were found there. In the lower part of the profile (samples Sk-1 - Sk-4) (Fig. 2) the occurrence of cold-tolerant species was noted. They were represented by both aquatic taxa typical for shallow water bodies with a rich vegetation: Pisidium stewarti Perston, P. obtusale lapponicum Cless. and higrophile snails Vertigo genesii (Gred.) and V. geyeri Lindh. (Table 1). In samples Sk-5 and Sk-6 (Fig. 2) the community was dominated by water molluscs, among others: Planorbis planorbis (L.), Valvata cristata Müll., Lymnaea peregra (Müll.), Pisidium casertanum (Poli), $P$. milium Held. Higrophile snails, such as Carychium minimum Müll. and Succinea putris (L.) constituted another important component of this community. A limited proportion of mesophile species (Euconulus fulvus (Müll.)) is noteworthy (Fig. 2, Table 1). Water molluscs with a considerable admixture of land snails (Fig. 2) indicate a shallow, marginal zone of the lake. The mollusc community associated with the lower interval corresponds to the cold climatic phase - probably Young Dryas or/and Preboreal Phase (S. W. Alexandrowicz 1989, S. W. AleXANDrowicz et al. 1989, LiMONDINE 1992, S. W. AleXANDROWICZ \& W. P. Alexandrowicz 1995a, b, W. P. AleXANDroWICZ \& SAN'KO 1997, W. P. ALEXANDROWICZ 1999). Species of limited climatic tolerance (Bithynia tentaculata (L.)) and euryoecious molluscs (Pisidium subtruncatum Malm.) are the main components of the malacocenose recognised in the upper part of the described sequence. This community indicates progressive amelioration of the climate (S. W. ALEXANDROWICZ 1987, 1989, W. P. ALEXANDROWICZ 1999).

Log Sk-II is composed of calcareous gyttja and lacustrine chalk overlain by peat (Fig. 2). Seven samples were collected from this section. In particular samples the number of taxa ranged from 6 to 19, with 38-1,279 specimens per sample. In the lower interval (samples Sk-7 - Sk-11) species preferring humid habitats, such as: Perforatella bidentata (Gmel.), Carychium minimum Müll. and Succinea putris (L.) prevailed, while water molluscs occurred sporadically (Fig. 2; Table 1). Sample Sk-13 indicates a short phase of development of the lake. Numerous shells of species typical for the temporary water bodies were found: Pisidium obtusale

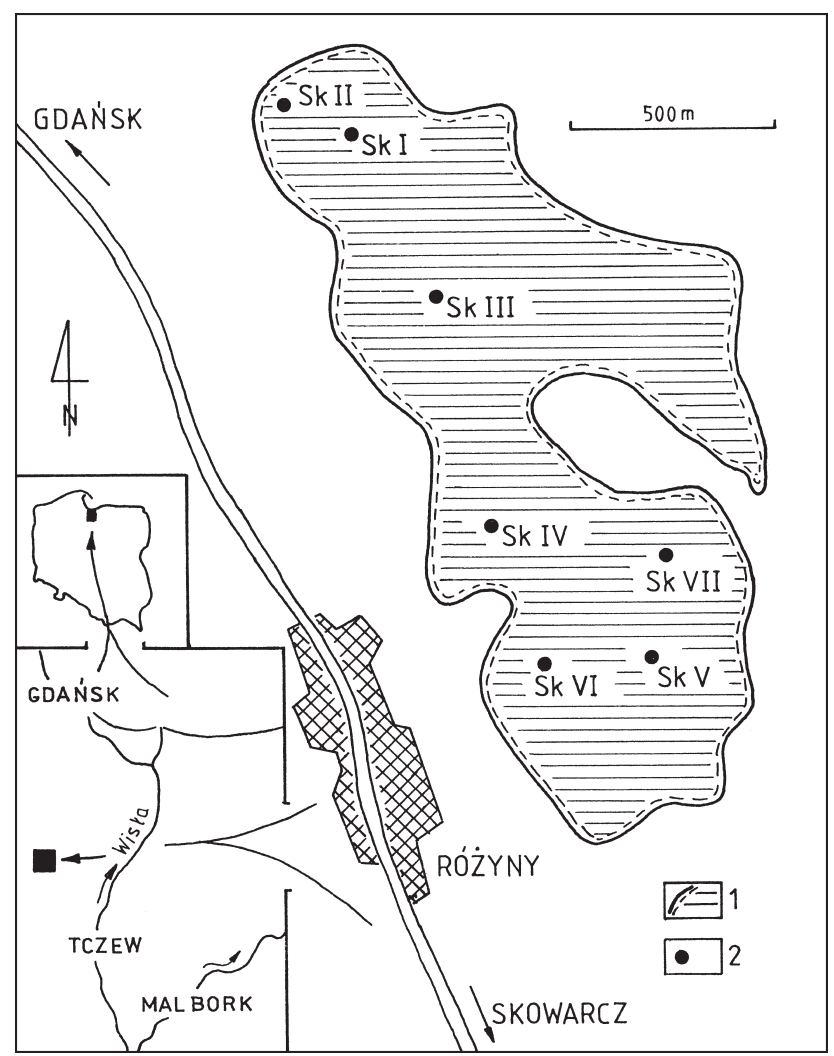

Fig. 1. Location of the profiles of Late Glacial and Early Holocene deposits in the ancient lake in Różyny: 1 - borders of the lake, 2 - bore-holes

(Lam.), Planorbis planorbis (L.) and others. The community dominated by meadow snails (Vallonia pulchella (Müll.)), accompanied by mesophile and higrophile taxa, occurred in the uppermost part of this log (sample Sk-13) (Fig. 2). The mollusc assemblage distinguished in the lower part of the profile developed close to the lake shore. It indicates swamps partly overgrown by alder wood. In the next phase the shore was flooded and transformed into shallow bay, and finally became completely overgrown and transformed into a wet meadow. The presence of Vertigo geyeri (Lindh.) in samples Sk-11 - Sk-13 points to Young Dryas and/or Early Holocene age of the mentioned sediments (S. W. ALEXANDROWICZ 1989, LIMONDINE 1992, W. P. ALEXANDROWICZ \& SAN'KO 1997, W. P. ALEXANDROWICZ 1999)

Log Sk-III includes lacustrine chalk alternating with peat (Fig. 2). In seven samples the number of species ranged from 10 to 18 , while the number of specimens reached 829. Two types of mollusc assemblages could be distinguished in this profile. One includes cold-loving bivalves, such as: Pisidium lilljeborgii Cless. and P. obtusale lapponicum Cless. accompanied by numerous taxa of wide ecological tolerance (Lymnaea peregra (Müll.), Gyraulus laevis (Ald.) and others). Higrophile snails, mainly Vertigo genesii (Gred.) and V. geyeri Lindh. complete this community. It represents the lower part of profile Sk-III (Fig. 2, 


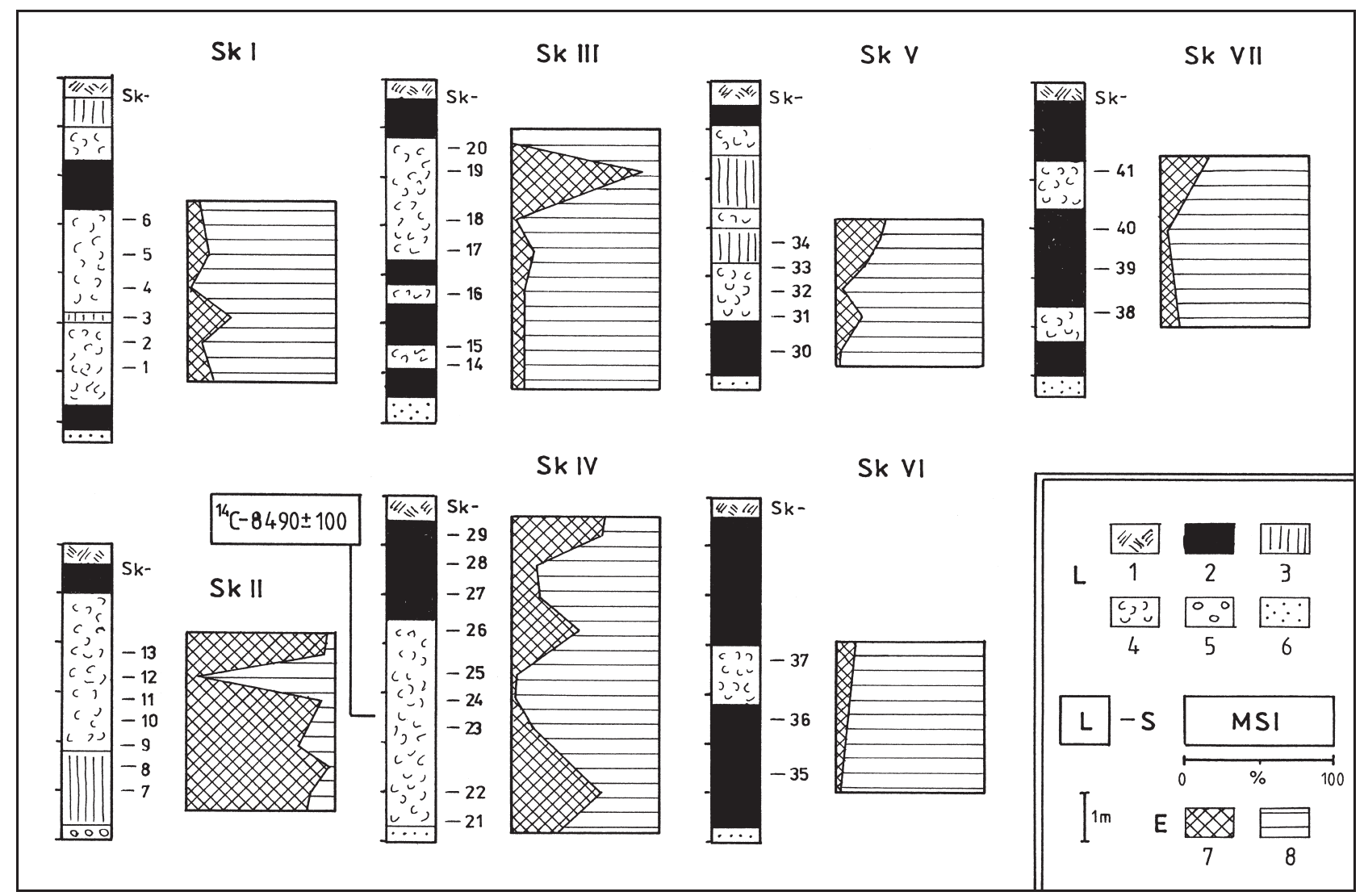

Fig. 2. Lithology and mollusc composition of the profiles from the ancient lake in Różyny.

L - Lithology: 1 - recent soil, 2 - peat, 3 - calcareous gyttja, 4 - lacustrine chalk, 5 - gravel, 6 - sand; S - Samples (Sk-); MSI - Malacological spectrum of individuals (based on LO EK 1964 and S.W. ALEXANDROWICZ 1987); E - Ecological groups of molluscs: 7 - land snails, 8 - water molluscs

Table 1). Such a fauna indicates a shallow water body. It is typical for cold climate and probably can be associated with Young Dryas. The uppermost part of the sequence contains a different assemblage. Species living in shallow water bodies with rich vegetation and preferring warmer climate, such as e.g. Bithynia tentaculata (L.), Anisus contortus (L.), prevailed there. The occurrence of molluscs inhabiting temporary water bodies (Planorbis planorbis (L.), Pisidium obtusale (Lam.)) is notheworthy (Fig. 2, Table 1). The community described above indicates progressive overgrowing of the lake and amelioration of climate. It corresponds with Early Holocene.

Lacustrine chalk overlain by peat was distinguished in log Sk-IV. Nine samples were collected from these deposits. The number of species per sample varied from 9 to 22, whereas the number of specimens reached up to 2,164. Samples Sk-21 and Sk-22 contained a rich mollusc assemblage with numerous shells of cold-loving bivalves (Pisidium lilljeborgii Cless. and $P$. obtusale lapponicum Cless.) and higrophile snails (Vertigo genesii (Gred.) and V. geyeri Lindh.). These molluscs were accompanied by several taxa of wide thermal tolerance. The occurrence of shells of meadow and mesophile species was noted (Fig. 2, Table 2). The presented community was associated with a shallow water basin surrounded by swamps and wet meadows. The composition and structure of this fauna are typical of the Young Dryas (S. W. ALEXANDROWICZ 1980, 1987, 1995, S. W. ALEXANDROWICZ et al. 1989, S. W. AleXANDrowicz \& W. P. AlEXANDroWICZ 1995a, b, W. P. ALEXANDROWICZ \& SAN'KO 1997, W. P. AleXANDROWICZ 1999). In the middle part of the sequence (samples Sk-23 - Sk-26) (Fig. 2) water molluscs characterising a flat, shallow and progressively overgrowing water body, such as: Bithynia tentaculata (L.), Valvata cristata Müll., Anisus contortus (L.), Lymnaea turricula (Held) and many others, were the prevailing components of the fauna. They were accompanied by euryoecious taxa (Pisidium casertanum (Poli), P. subtruncatum (Malm), Lymnaea peregra (Müll.)). A limited proportion of snails typical for the moderately warm climate - Vertigo moulinsiana (Dup.) - was noted (Table 2). Sediments containing the described community can be assigned to Early Holocene. Such an interpretation is supported by the radiocarbon date: $8,490 \pm 100$ years $\mathrm{BP}(\mathrm{Gd}-5123)$. The fauna found in peat (samples Sk-27 - Sk-29) is characterised by a high proportion of land snails (Fig. 2, Table 2 ). It indicates progressive overgrowing of the water body and its transformation into a wet meadow during the Atlantic Phase of Holocene. 
Table 1. Malacofauna of the ancient lake Różyny (profiles Sk-I - Sk-III)

E: ecological groups (based on LO EK 1964 and S. W. ALEXANDROWICZ 1987): 2. species inhabiting mainly forests, 3. species of humid forests, 5. open-country species, 7. mesophile species of moderately humid environments, 8. mesophile species of humid environments, 9. higrophile species, 10. species inhabiting temporary water bodies, 11 . species inhabiting permanent water bodies, 12. species inhabiting flowing waters; number of specimens: $1-1-3,2-$ 4-10, 3-11-32, 4-33-100, 5-101-316, 6-317-1000 (based on S. W. ALEXANDROWICZ 1987).

\begin{tabular}{|c|c|c|c|c|c|c|c|c|c|c|c|c|c|c|c|c|c|c|c|c|c|}
\hline \multirow{3}{*}{$\mathrm{E}$} & \multirow{3}{*}{ TAXON } & \multicolumn{6}{|c|}{ Sk-I } & \multicolumn{7}{|c|}{ Sk-II } & \multicolumn{7}{|c|}{ Sk-III } \\
\hline & & 1 & 2 & 3 & 4 & 5 & 6 & 7 & 8 & 9 & 1 & 1 & 1 & 1 & 1 & 1 & 1 & 1 & 1 & 1 & 2 \\
\hline & & & & & & & & & & & 0 & 1 & 2 & 3 & 4 & 5 & 6 & 7 & 8 & 9 & 0 \\
\hline 2 & Bradybaena fruticum & & & & & & & & 1 & 2 & & & & & & & & & & 1 & \\
\hline 3 & Perforatella bidentata & & & & & & & 3 & 3 & 3 & 3 & 3 & & & & & 1 & & & 1 & \\
\hline 5 & Vertigo pygmaea & & & & & & & & & & & 1 & & & & & & & & & \\
\hline 5 & Pupilla muscorum & & 1 & & & & & & & & & & & & & & & & & & \\
\hline 5 & Vallonia costata & & & & & & & & & & & 3 & 3 & 3 & & & & & & & \\
\hline 5 & Vallonia pulchella & & 1 & & 1 & 1 & 1 & 1 & 2 & 2 & 3 & 3 & 4 & 4 & 1 & & & 2 & 1 & 2 & \\
\hline 7 & Cochlicopa lubrica & & & & & & & & & & 3 & 2 & 1 & 2 & & & & & & & \\
\hline 7 & Punctum pygmaeum & & & & & & & & & & & & & & & & & & & & \\
\hline 7 & Nesovitrea hammonis & & & & & & & & 1 & 2 & 3 & 2 & & 2 & & & & & & 1 & \\
\hline 7 & Euconulus fulvus & 1 & & & 2 & 3 & 3 & 1 & 1 & & 3 & 2 & & 2 & & 1 & & 2 & & 2 & \\
\hline 8 & Carychium tridentatum & & & & & & & & & & & 3 & & 3 & & & & & & & \\
\hline 8 & Vertigo angustior & & & & & & & & & & & & 1 & 3 & & & & & & & \\
\hline 8 & Succinea oblonga & & & & & & & & & 1 & & & & & & & & & & & \\
\hline 8 & Nesovitrea petronella & & & & & 2 & 1 & & & & & & 1 & & & & & & & & \\
\hline 9 & Carychium minimum & 3 & & 4 & 4 & 4 & 4 & 2 & 3 & 3 & 5 & 3 & 4 & 3 & 3 & & 2 & 3 & 1 & 2 & \\
\hline 9 & Vertigo antivertigo & 1 & 1 & 3 & 1 & 2 & 2 & & & & & & & & 2 & 3 & & 3 & 1 & & \\
\hline 9 & Vertigo genesii & 2 & 3 & 3 & & & & & & & 1 & & & & & 3 & & & & & \\
\hline 9 & Vertigo geyeri & 2 & 3 & 3 & & & & & & & & 1 & 3 & 4 & & 3 & & 3 & & 1 & \\
\hline 9 & Succinea putris & 3 & 2 & 3 & & 3 & 3 & 1 & 1 & 1 & 2 & 1 & 3 & & & 3 & 3 & 4 & 1 & & \\
\hline 9 & Succinea elegans & 2 & & 3 & & 3 & 3 & & & & & & 3 & & & & & & & & \\
\hline 9 & Monachoides rubiginosa & & & & 2 & & 2 & & & & & & 2 & & & & & & & & \\
\hline 10 & Lymnaea truncatula & & & & 4 & & & 1 & 1 & 2 & 3 & 1 & & 3 & 3 & 3 & & & & 1 & \\
\hline 10 & Lymnaea occulta & & & & 3 & 3 & 4 & & & & & & & & & 4 & & 4 & & & \\
\hline 10 & Planorbis planorbis & 3 & 3 & 4 & 5 & 5 & 5 & & & & & & 4 & & 4 & 4 & 3 & 4 & 3 & & 3 \\
\hline 10 & Pisidium obtusale & & & & & & 3 & & & & & & 5 & & 3 & & 4 & 3 & 3 & & 3 \\
\hline 11 & Valvata cristata & 4 & 2 & 3 & 5 & 4 & 5 & & & & & & 5 & & 4 & 5 & 4 & 5 & 4 & & 4 \\
\hline 11 & Bithynia tentaculata & & & & & 3 & 4 & & & & & & 4 & & & & 3 & 4 & 1 & 3 & 3 \\
\hline 11 & Stagnicola palustris & 3 & 3 & 3 & 5 & 4 & 5 & & & & 3 & & 5 & & 4 & & 3 & 4 & 3 & & \\
\hline 11 & Lymnaea turricula & 3 & & & 5 & 4 & 4 & & & & & & 3 & & 2 & 4 & & 3 & & & 3 \\
\hline 11 & Lymnaea peregra & 4 & 4 & 4 & 6 & 5 & 5 & & & 3 & & & 5 & & 4 & 5 & 4 & 5 & 3 & & 4 \\
\hline 11 & Anisus vortex & 2 & & 2 & 4 & 3 & 3 & & & & & & & & 3 & 3 & 3 & 3 & 2 & & 3 \\
\hline 11 & Anisus contortus & 3 & 2 & 3 & 4 & 3 & 3 & & & & & & & & 3 & 3 & 4 & 4 & 3 & 1 & 3 \\
\hline 11 & Gyraulus laevis & 3 & & & 4 & 4 & 4 & & & & & & 3 & & 3 & 3 & 3 & & & & \\
\hline 11 & Gyraulus acronicus & & & & & & & & & & & & & & 3 & & & & & & \\
\hline 11 & Acroloxus lacustris & 1 & & & & & & & & & & & & & & & & & & & \\
\hline 11 & Pisidium milium & 4 & 2 & 4 & 5 & 3 & 4 & & & & & & 5 & & 3 & & 3 & 4 & 3 & & 2 \\
\hline 11 & Pisidium subtruncatum & & & 3 & 3 & 3 & 4 & & & & 3 & 2 & 4 & 3 & & & & 4 & 2 & & \\
\hline 11 & Pisidium lilljeborgii & 1 & 1 & & & & & & & 1 & & & & & 3 & 3 & & & & & \\
\hline 11 & Pisidium casertanum & 3 & & & 4 & 3 & 3 & & & & & 2 & & & & & & & & & 3 \\
\hline 11 & Pisidium obtusale lapponicum & 2 & 2 & & & & & & & & & & & & 3 & 4 & & & & & \\
\hline 11 & Pisidium stewarti & 3 & 2 & 2 & & & & & & & & & & & & & & & & & \\
\hline 11 & Pisidium moitessierianum & & & & & & & & & & & & & & & & & & 3 & & \\
\hline 12 & Pisidium nitidum & & & & & & 3 & & & & & & & & & & 3 & & & & \\
\hline
\end{tabular}


Table 2. Malacofauna of the ancient lake Różyny (profiles Sk-IV - Sk-VII).

For explanation see Table 2.

\begin{tabular}{|c|c|c|c|c|c|c|c|c|c|c|c|c|c|c|c|c|c|c|c|c|c|c|}
\hline \multirow{3}{*}{$\mathrm{E}$} & \multirow{3}{*}{ TAXON } & \multicolumn{9}{|c|}{ Sk-IV } & \multicolumn{5}{|c|}{ Sk-V } & \multicolumn{3}{|c|}{ Sk-VI } & \multicolumn{4}{|c|}{ Sk-VII } \\
\hline & & 2 & 2 & 2 & 2 & 2 & 2 & 2 & 2 & 2 & 3 & 3 & 3 & 3 & 3 & 3 & 3 & 3 & 3 & 3 & 4 & 4 \\
\hline & & 1 & 2 & 3 & 4 & 5 & 6 & 7 & 8 & 9 & 0 & 1 & 2 & 3 & 4 & 5 & 6 & 7 & 8 & 9 & 0 & 1 \\
\hline 3 & Perforatella bidentata & & & & & & & 1 & & 1 & & & & & & & & & & & & \\
\hline 5 & Vertigo pygmaea & & & & & & & & 3 & & & & & & & & & & & & 1 & \\
\hline 5 & Pupilla muscorum & 1 & 3 & & & & & & & 3 & & & & & & & & & & & & \\
\hline 5 & Vallonia costata & & & & & & & & & 3 & & & & & & & & & & & & \\
\hline 5 & Vallonia pulchella & & 3 & 2 & 2 & 3 & 1 & & 2 & 4 & & 2 & 2 & & 2 & & & 2 & & & 2 & 2 \\
\hline 7 & Cochlicopa lubrica & 1 & & & & & & & & 3 & & & & & & & & & & & & \\
\hline 7 & Punctum pygmaeum & & & & & & & & & 1 & & & & & & & & & & & & \\
\hline 7 & Nesovitrea hammonis & & & & & & & & 2 & & & & & & & & & & & & & \\
\hline 7 & Euconulus fulvus & 1 & 3 & & & & 2 & 1 & & & & & & 1 & 2 & & 1 & 2 & & 1 & 2 & 1 \\
\hline 7 & Trichia hispida & 1 & & & & & & & & 3 & & & & & & & & & & & & \\
\hline 8 & Carychium tridentatum & & & & & & & & & 4 & & & & & & & & & & & & \\
\hline 8 & Columella edentula & & & & & & & & & & & & & & 1 & & & 1 & & & & \\
\hline 8 & Vertigo angustior & & & & & & & & & 3 & & & & & & & & & & & & \\
\hline 8 & Succinea oblonga & & & & & & & & & 2 & & & & & & & & & & & & \\
\hline 8 & Nesovitrea petronella & & & & & & 1 & & & & & & & & & & & & & & & \\
\hline 9 & Carychium minimum & & & 3 & & 4 & 3 & & 3 & 3 & 4 & 3 & 3 & & 3 & 4 & & 3 & & 2 & 2 & 2 \\
\hline 9 & Cochlicopa nitens & & & & & & & & & 2 & & & & & & & & & & & & \\
\hline 9 & Vertigo antivertigo & & & & & 2 & & & & 3 & & & 1 & 3 & 3 & & 4 & 3 & & 2 & & \\
\hline 9 & Vertigo moulinsiana & & & & & 2 & & & & & & & & & 1 & & & 1 & & & 1 & \\
\hline 9 & Vertigo genesii & 2 & 4 & & & & & & & & & & & & & & & & 3 & 1 & & \\
\hline 9 & Vertigo geyeri & 3 & 2 & & & & & & & & 3 & 3 & & 1 & 3 & 3 & 1 & 3 & 4 & 2 & & \\
\hline 9 & Succinea putris & 3 & 3 & 3 & 3 & 3 & & & 3 & 3 & 4 & 3 & 3 & 3 & 3 & 4 & 3 & 3 & 3 & 3 & 3 & \\
\hline 9 & Succinea elegans & & & 2 & & & & & & & & & & & & & & & & & 2 & \\
\hline 10 & Valvata pulchella & & & & 2 & & & & & & & & & & & & & & & & & \\
\hline 10 & Aplexa hypnorum & & 1 & & & & & & & & & & & & & & & & & & & \\
\hline 10 & Lymnaea truncatula & 2 & & 3 & & 5 & 3 & 1 & 3 & 4 & 4 & & & & & 4 & & & 3 & & 2 & \\
\hline 10 & Lymnaea occulta & & & 3 & & 5 & 4 & 3 & 3 & & 5 & & & 4 & & 5 & 4 & & & & 4 & \\
\hline 10 & Planorbis planorbis & 1 & & 4 & & 4 & & 2 & 3 & 3 & 5 & & 4 & 4 & 3 & 5 & 4 & 4 & & 3 & 5 & \\
\hline 10 & Pisidium obtusale & & & & & & & & 3 & & 4 & 3 & 3 & 3 & & & & & & & 4 & 2 \\
\hline 11 & Valvata piscinalis & & & & & & & & & & & & 4 & & & & & & 2 & & & \\
\hline 11 & Valvata cristata & 2 & 2 & 4 & 6 & 6 & 2 & 1 & 5 & 4 & 6 & 4 & 5 & 5 & 5 & 6 & 5 & 5 & 4 & 5 & 5 & 3 \\
\hline 11 & Bithynia tentaculata & & & 4 & 4 & 5 & & & 4 & 3 & 5 & 3 & 5 & 3 & 4 & 5 & 3 & 4 & 3 & 4 & 5 & 4 \\
\hline 11 & Stagnicola palustris & 3 & 3 & 3 & 4 & 4 & 3 & 3 & 4 & & 5 & 3 & 5 & 4 & 4 & 5 & 4 & 4 & 4 & 3 & 3 & \\
\hline 11 & Lymnaea turricula & & & 3 & & 5 & 5 & 5 & 5 & & 4 & & 4 & 3 & & 4 & 3 & & 3 & & 4 & \\
\hline 11 & Lymnaea peregra & & & 3 & 5 & 5 & 5 & 5 & 4 & 3 & 5 & 4 & 5 & 5 & 4 & 5 & 5 & 4 & 4 & 4 & 4 & 1 \\
\hline 11 & Planorbarius corneus & & & & & & & & & & & & 3 & & & & & & & & & \\
\hline 11 & Anisus vortex & & & 3 & 4 & 4 & & & 3 & & 5 & 3 & 4 & 3 & 3 & 5 & 3 & 4 & 3 & 3 & 3 & 2 \\
\hline 11 & Anisus vorticulus & & & & & & & & 3 & & & & & & & & & & & 2 & 1 & \\
\hline 11 & Anisus contortus & & 3 & 3 & 4 & 4 & & & 3 & & 5 & 3 & 4 & 3 & 3 & 5 & 3 & 3 & 3 & 3 & 4 & \\
\hline 11 & Gyraulus albus & & & & & 4 & & & & & & & & & & 4 & & & & & 2 & \\
\hline 11 & Gyraulus laevis & & & 2 & & 3 & & 2 & & & 4 & & & & & & & & 3 & & 2 & \\
\hline 11 & Armiger crista & & & & & & & & & & 5 & & & & & 5 & & & 4 & & & 1 \\
\hline 11 & Pisidium milium & & & 3 & 4 & 5 & & & 4 & 3 & 5 & 3 & 5 & 4 & 4 & 5 & 4 & 4 & 3 & 4 & 4 & \\
\hline 11 & Pisidium subtruncatum & & & & 4 & 5 & 1 & & 4 & 3 & 5 & 3 & 4 & 4 & 4 & 5 & 4 & 4 & 3 & 4 & 3 & \\
\hline 11 & Pisidium lilljeborgii & 4 & 3 & & & & & & & & & & & & & & & & 2 & & & \\
\hline 11 & Pisidium casertanum & & & 3 & & 5 & 2 & & & 2 & 4 & & 3 & & & 4 & & & & & & \\
\hline 11 & Pisidium obtusale lapponicum & 3 & 2 & & & & & & & & & & & & & 4 & 3 & & 2 & 3 & & \\
\hline 12 & Pisidium nitidum & & & 3 & & 3 & & & & & 3 & & & & & 3 & & & & & 3 & \\
\hline
\end{tabular}


Lacustrine chalk and calcareous gyttja underlain and covered by peat occur in log Sk-V. Five samples rich in shells of snails and bivalves were collected. They contained a fauna with numerous taxa of water molluscs: Lymnaea peregra (Müll.), L. turricula (Held), Stagnicola palustris (Müll.) and others. The assemblage corresponds with a permanent water body with rich vegetation. Land snails are subordinate components of this fauna (Fig. 2, Table 2). The community in question is probably associated with Early Holocene.

Log Sk-VI is composed of peat separated by lacustrine chalk (Fig. 2). Three samples were collected from this section. Water molluscs typical for permanent water bodies (Lymnaea peregra (Müll.), Stagnicola palustris (Müll.), Valvata cristata Müll., Lymnaea turricula (Held), Anisus contortus (L.) and many others) were the dominant components of this fauna

\section{MOLLUSC ASSEMBLAGES}

Subfossil shells of snails and bivalves occur frequently in Late Glacial and Holocene deposits filling the ancient lake in Różyny. The composition and structure of mollusc communities are related to environmental and climatic changes. Several types of such assemblages can be distinguished in the studied site.

\section{THE VALLONIA PULCHELLA ASSEMBLAGE [VPU]}

The fauna in question is dominated by open-country snails, mainly Vallonia pulchella (Müll.) and V. costata (Müll.), accompanied by numerous mesophile and higrophile ones: Cochlicopa lubrica (Müll.), Succinea oblonga Drap., Vertigo antivertigo (Drap.), Succinea putris (L.) and others. The occurrence of molluscs inhabiting temporary water bodies (Lymnaea truncatula (Müll.), Planorbis planorbis (L.)) is usually noted. The mentioned community is associated with sediments covering lake deposits. It indicates the last stage of development of ancient lake and phase of it transformation into wet meadow probably during the Atlantic Phase of Holocene. This fauna was found in the uppermost part of logs Sk-II and Sk-IV (Fig. 3).

\section{THE PERFORATELLA BIDENTATA ASSEMBLAGE $[\mathrm{PB}]$}

This poor community is characterised by the dominance of Perforatella bidentata (Gmel.), accompanied by higrophile snails such as Succinea putris (L.) and Zonitoides nitidus (Müll.). Species living in temporary water bodies (Lymnaea truncatula (Müll.), Planorbis planorbis (L.)) are supplementary components. The described fauna has developed within an alder wood on the shores of the lake during the Preboreal and
(Fig. 2, Table 2). The occurrence of cold-tolerant taxa: Pisidium obtusale lapponicum Cless. and Vertigo geyeri Lindh. was noted. The described sequence represents Early Holocene.

Four samples were collected from log Sk-VII, containing lacustrine chalk alternating with peat (Fig. 2). Water species of permanent water bodies with rich vegetation (Bithynia tentaculata (L.), Lymnaea peregra (Müll.), Stagnicola palustris (Müll.), Valvata cristata Müll., Lymnaea turricula (Held), Anisus contortus (L.) and others) were the main components of the fauna (Fig. 2, Table 2). In the lower part of the section numerous shells of cold-tolerant taxa, such as: Vertigo genesii (Gred.), V. geyeri Lindh., Pisidium obtusale lapponicum Cless. and P. lilljeborgii Cless. were found. The assemblage corresponds with a water body of rich vegetation and points to a Young Dryas and Early Holocene age of the mentioned sediments.

Boreal Phases and at the beginning of Atlantic Phase. It was recognised in profile Sk-II (Fig. 3).

\section{THE VERTIGO GENESII AND V. GEYERI ASSEMBLAGE [VG, VGE]}

The above taxa supplemented by cold-tolerant water molluscs such as Pisidium obtusale lapponicum Cless., P. lilljeborgii Cless., Gyraulus laevis (Ald.) as well as by higrophile species, like Succinea putris (L.), are the main components of this fauna. The mentioned community is regarded as typical for the Young Dryas (S. W. AleXANDrowicz 1989, 1995, S. W. ALEXANDROWICZ et al. 1989, LiMONDINE 1992, S. W. ALEXANDROWICZ \& W. P. ALEXANDROWICZ 1995a, b, W. P. Alexandrowicz \& SAN'Ko 1997, W. P. ALEXANDROWICZ 1999). It inhabited woodless areas and humid habitats such as swamps and marshes, widespread under cold climatic conditions. The fauna in question occurs in the lowermost part of profiles Sk-I, Sk-IV and Sk-VII (Fig. 3).

\section{THE GYRAULUS LAEVIS AND PISIDIUM OBTUSALE LAPPONICUM ASSEMBLAGE [GL, POL]}

These taxa, accompanied by Pisidium lilljeborgii Cless., P. stewarti Per. and other cold-tolerant water species are the most important components of this community. A limited proportion of higrophile snails: Vertigo genesii (Gred.), V. geyeri Lindh. is the characteristic feature of the described fauna. This assemblage inhabits small, shallow water bodies or flat zones of big lakes. It can be regarded as typical for the Late Glacial (S. W. ALEXANDROWICZ 1981, 1987, 1995, S. W. ALEXANDROWICZ et al. 1998, S. W. ALEXANDROWICZ \& W. P. AleXANDrowicz 1995a, W. P. AleXANDROWICZ 
1999). This fauna was found in the lowermost part of log Sk-III (Fig. 3).

\section{THE PLANORBIS PLANORBIS ASSEMBLAGE [PP]}

It is a community comprising two groups of molluscs. One is represented by taxa living in temporary water bodies, such as Planorbis planorbis (L.), Lymnaea truncatula (Müll.), Pisidium obtusale (Lam.) accompanied by euryoecious water molluscs (Lymnaea peregra (Müll.), Stagnicola palustris (Müll.), Lymnaea turricula (Held), Anisus vortex (L.), A. contortus (L.), Pisidium casertanum (Poli), P. subtruncatum Malm). Higrophile land snails (Succinea putris (L.), S. elegans Risso, Perforatella rubiginosa (A. Sham.)) belong to the second group. This fauna is typical for peat-bogs and found in the upper part of the log Sk-II (Fig. 3).

\section{THE BITHYNIA TENTACULATA ASSEMBLAGE [BT]}

The fauna is characterised by the dominance of molluscs living in lakes and water bodies partly open and partly overgrown by bulrush. Shells and opercula of Bithynia are its principal components. Numerous other water species of limited climatic tolerance, like Anisus contortus (L.), A. vortex (L.) and others are also noted. Cold-loving species are absent or can be regarded as accessory elements of the community. Bithynia is represented mainly by opercula, while shells occur rarely. It is typical for the shallow zones of lakes overgrown by bulrush (STEENBERG 1917, S. W. ALEXANDROWICZ 1980, 1987, 1989, S. W. ALEXANDROWICZ \& TCHÓRZEWSKA 1981, W. P. ALEXANDROWICZ \& SAN'KO 1997, W. P. AlEXANDROWICZ 1999). The mentioned fauna corresponds with the Early Holocene. It was found in profiles Sk-IV and Sk-VII (Fig. 3).

\section{CONCLUSIONS}

Communities of molluscs have been associated with ancient habitats in relation to the climate. The assemblages described above reflect the evolution of the lake basin in Różyny near Skowarcz during the Late Glacial and Early Holocene. Particular types of fauna correspond with phases of formation, development, declining, and filling of the lake, gradually transformed into a peat-bog, swamps and finally into a wet meadow.

The first phase of development of the lake in Różyny corresponds with Young Dryas. During this period small, temporary or permanent kettles, usually overgrown by plants were scattered in the lake basin. They were inhabited by a fauna abounding in coldtolerant water species (the Gyraulus laevis and

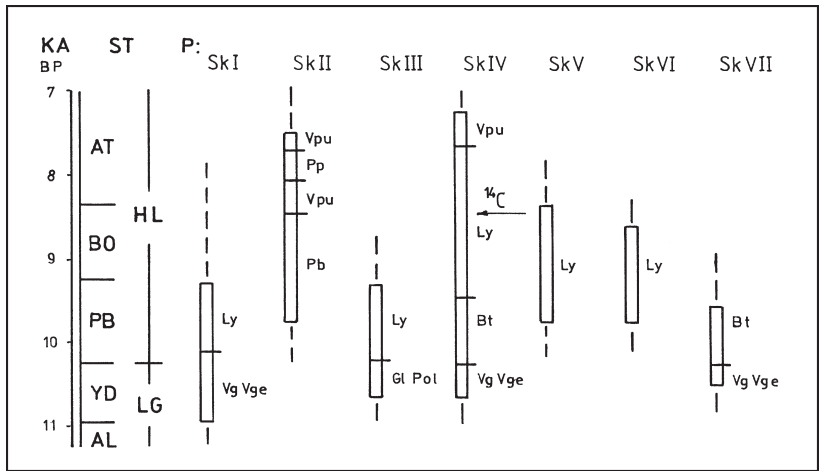

Fig. 3. Mollusc assemblages in the profiles from the ancient lake in Różyny

KA - age BP in thousands of years; ST - stratigraphy: AL - Alleröd, YD - Young Dryas, PB - Preboreal, BO Boreal, AT - Atlantic, LG - Late Glacial, HL - Holocene; for the lettering of the profiles see Fig 1; Malacofauna: $\mathrm{Bt}$ - Bithynia tentaculata (L), Vg - Vertigo genesii (Gred.), Vge - Vertigo geyeri Lind., Ly - Lymnaeidae, $\mathrm{Pb}-$ Perforatella bidentata (Gmel.), Vpu - Vallonia pulchella (Müll.), Gl - Gyraulus laevis (Ald.), Pol - Pisidium obtusale lapponicum Cless., $\mathrm{Pp}$ - Planorbis planorbis (L.)

\section{THE LYMNAEA ASSEMBLAGE [LY]}

This richest community found in lacustrine chalk filling the ancient lake in Różyny is composed of water snails of wide ecological tolerance: Lymnaea peregra (Müll.), Stagnicola palustris (Müll.), Lymnaea turricula (Held), Anisus vortex (L.), A. contortus (L.), Pisidium milium Held, P. casertanum (Poli), P. subtruncatum Malm and others. Land snails occur sporadically. This fauna, inhabiting both big lakes and small shallow water bodies, was commonly reported from Holocene lake sediments (BRODNIEWICZ 1978, S. W. ALEXANDROWICZ 1989, 1998, S. W. AlEXANDROWICZ et al. 1989, W. P. ALEXANDROWICZ 1999, WOJCIECHOWSKI 2000 and others) (Fig. 3).

Pisidium obtusale lapponicum assemblage). Young Dryas was the maximum phase of development of swamps and marshes. It is evidenced by the wide distribution of the community with a high proportion of cold-loving snails preferring humid habitats (the Vertigo genesii and $V$. geyeri assemblage) ( $\mathrm{S}$. W. ALEXANDROWICZ 1989, 1995, S. W. ALEXANDROWICZ et al. 1989, S. W. AleXANDrowicz \& W. P. AlEXANDROWICZ 1995a, b, W. P. ALEXANDROWICZ \& SAN'KO 1997, W. P. AlEXANDROWICZ 1999) (Fig. 4).

Following the progressive amelioration of the climate during the Early Holocene, the mentioned fauna became gradually enriched with taxa typical for moderately warm zone, while the percentage of cold-tolerant species decreased markedly. During the 


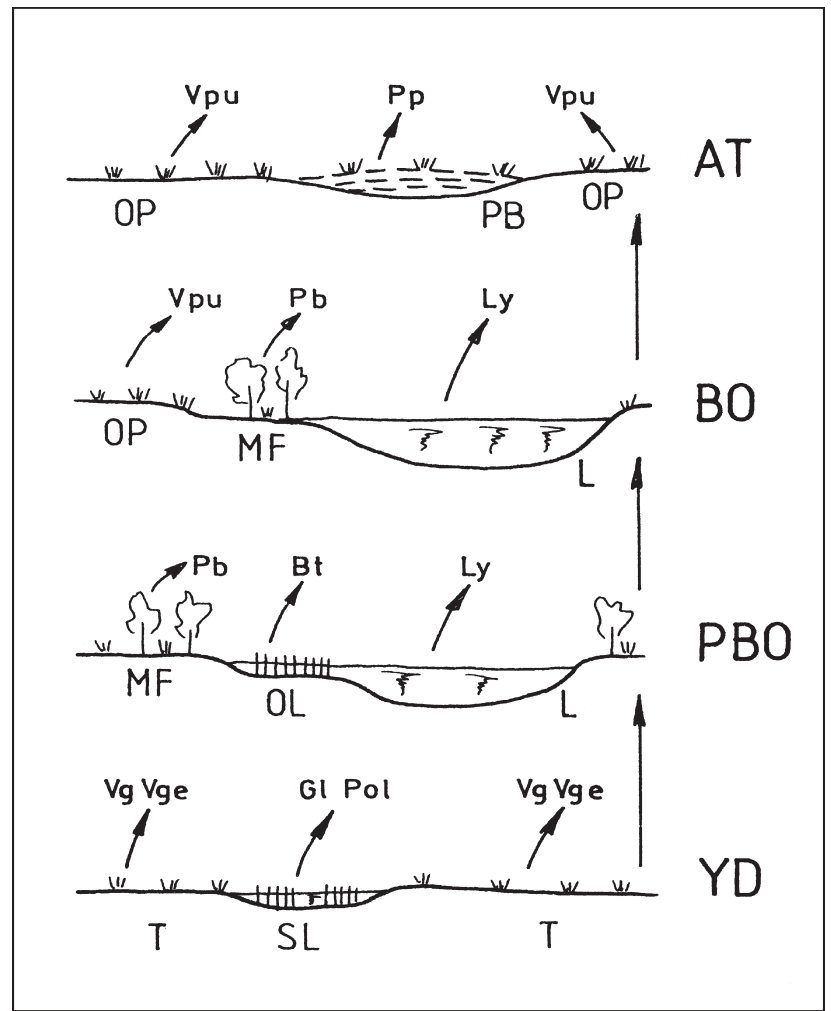

Fig. 4. Scheme of evolution of the ancient lake in Różyny during Late Glacial, Early and Middle Holocene YD - Young Dryas, PBO - Preboreal, BO - Boreal, AT Atlantic; $\mathrm{T}$ - subarctic tundra, $\mathrm{SL}$ - shallow water bodies, OL - overgrown water bodies, PB - peat-bogs, OP open environment, MF - woodland environment, L lake. Malacofauna: Bt - Bithynia tentaculata (L), Vg Vertigo genesii (Gred.), Vge - Vertigo geyeri Lind., Ly Lymnaeidae, $\mathrm{Pb}$ - Perforatella bidentata (Gmel.), Vpu Vallonia pulchella (Müll.), Gl - Gyraulus laevis (Ald.), Pol - Pisidium obtusale lapponicum Cless., Pp - Planorbis planorbis (L.)

Preboreal and Boreal Phases the shallow kettle transformed gradually into a larger and deeper lake with a rich plant vegetation. The central part of this basin was inhabited by a differentiated community of water molluscs (the Lymnaea assemblage). The fauna with a high porportion of opercula of Bithynia tentaculata (L.) developed in the marginal zones overgrown by bulrush (assemblage with Bithynia tentaculata). Lacustrine chalk containing the assemblage with Lymnaea was dated with radiocarbon method at $8,490 \pm 100$ years BP (Gd-5123). Communities with dominance of land snails represent shores of the lake. Two types of environments can be distinguished. Alder wood and humid wooded areas were inhabited by the fauna with predominance of Perforatella bidentata (Gmel.), while the occurrence of wet meadows is evidenced by the assemblage with Vallonia pulchella (Müll.) (Fig. 4). The main phase of accumulation of calcareous gyttja and lacustrine chalk corresponds with the described period. The lake was gradually filled by these deposits. Peat overlaying calcareous deposits, connected with the Atlantic Phase marked the last stage of development of the ancient lake in Różyny. In the central part of the basin small, flat, shallow and mostly temporary water bodies were inhabited by the Planorbis planorbis assemblage. Marginal zones of the lake were completely overgrown and transformed into a wet meadow. The Vallonia pulchella assemblage corresponds with these areas (Fig. 4).

The succession of the mollusc assemblages indicates phases of development of the lake in Różyny during the Late Glacial and Holocene. The first stage of evolution of the water body is associated with the Young Dryas. Several lakes and depressions filling temporary with water have being formed during this period (W. P. ALEXANDROWICZ 1999, WOJCIECHOWSKI 2000). The small, initial kettle developed in local melt depression was inhabited by a poor assemblage with a high proportion of cold-loving water molluscs. It was surrounded by woodless, humid, tundra-type landscape. During the Early Holocene the mentioned kettle transformed into a shallow lake with rich plant vegetation. It was inhabited by differentiated mollusc communities dominated by euryoecious water species. Swamps, marshes and wet meadows, partly covered by alder woods occurred on the shores of the lake. At the end of the Boreal Phase the gradual lowering of ground water level was observed (STARKEL 1977, RALSKA-JASIEWICZOWA \& STARKEL 1988, W. P. ALEXANDROWICZ 1999, WOJCIECHOWSKI 2000). This process and the progressive development of vegetation as well as filling with sediments were the main factors responsible for the decline of the lake and its transformation into a peat-bog and finally into a wet meadow.

Two main sequences of the mollusc fauna can be distinguished in deposits filling the ancient lake in Różyny. They reflect changes of environment during the Young Dryas, Late and Middle Holocene. The first sequence corresponds with the shores of a lake (Fig. 5 $\mathrm{SH})$. During the Young Dryas the fauna was dominated by marsh-dwelling snails preferring cold climate (Vertigo genesii (Gred.), V. geyeri Lindh.) accompanied by higrophile species of wide thermal tolerance (Succinea putris (L.), S. elegans Risso). Since the beginning of the Holocene the number of taxa of more limited climatic tolerance increase markedly. Shores of the lake were partly overgrown by alder wood. Shade-loving species such as Perforatella bidentata (Gmel.) appeared in these zones. The alder wood was surrounded by open, moist and swampy areas inhabited by meadow, higrophile taxa and even by water molluscs typical for temporary kettles: Vallonia pulchella (Müll.), Carychium minimum Müll., Planorbis planorbis (L.), Pisidium obtusale (Lam.) and others. During the Middle Holocene wet meadows became the dominant type of shore habitat (Fig. 5).

The second type of mollusc sequence corresponds with the evolution of the water body (Fig. 5 LK). A 


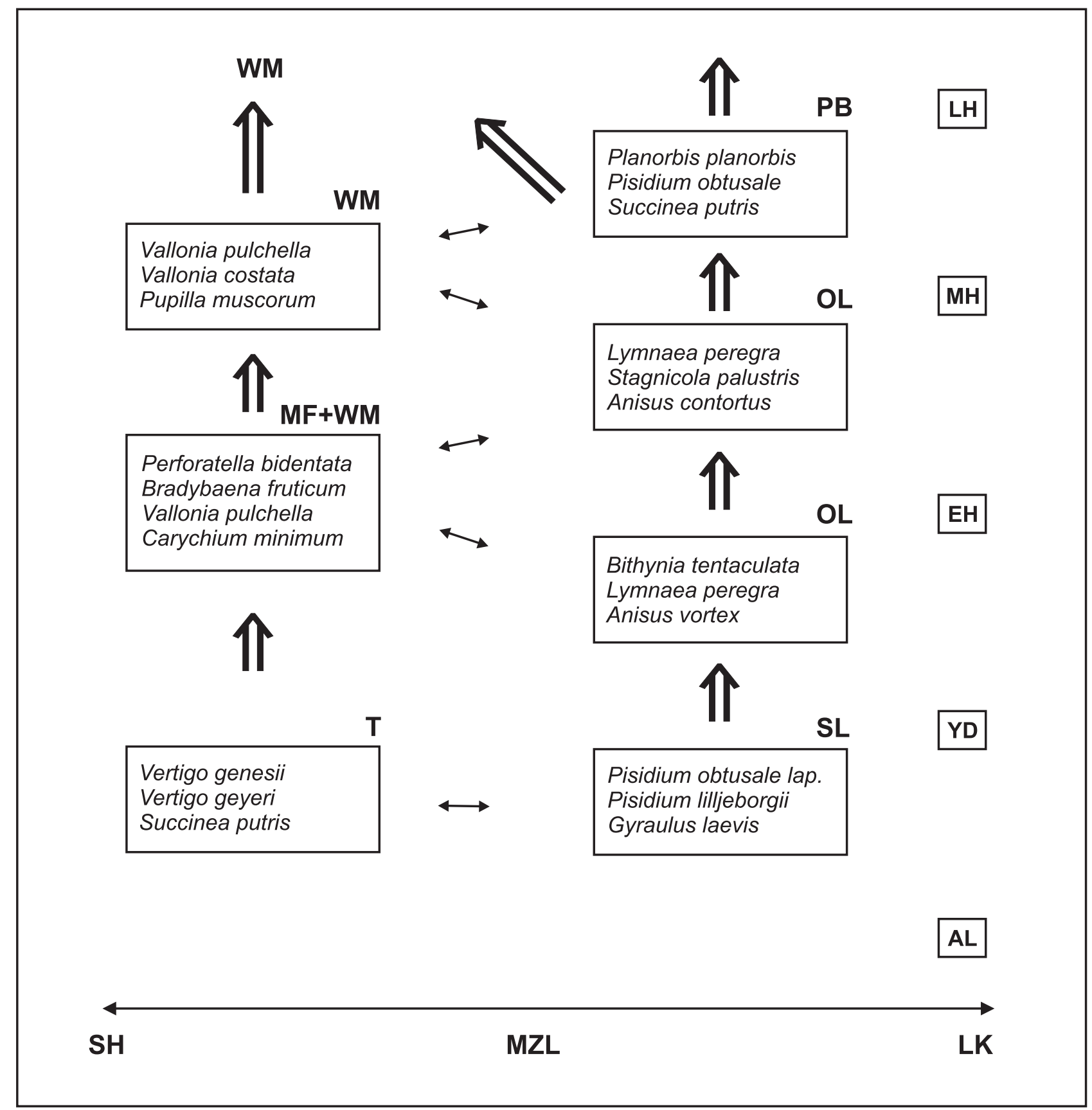

Fig. 5. Mollusc successions of the Late Glacial, Early and Middle Holocene sediments filling the ancient lake in Różyny SH - Shores of the lake, MZL - Marginal zone of the lake, LK - Lake; AL - Alleröd, YD - Yuong Dryas, EH - Early Holocene, MH - Middle Holocene, LH - Late Holocene; T - subarctic tundra, SL - shallow water bodies, OL overgrown water bodies, $\mathrm{PB}$ - peat-bogs, $\mathrm{WM}$ - wet meadows, MF - moist forests

shallow water basin was formed most probably during the Younger Dryas. It was inhabited by cold-tolerant water species such as: Pisidium obtusale lapponicum Cless., P. lilljeborgii Cless., P. stewarti Pers., Gyraulus laevis (Ald.). At the beginning of the Holocene this kettle transformed into a larger and deeper lake with rich vegetation. Cold-loving taxa were gradually replaced by molluscs preferring warmer climate: Bithynia tentaculata (L.), Lymnaea peregra (Müll.), L. turricula (Held), Stagnicola palustris (Müll.), Anisus vortex (L.) and many others. The Early Holocene age of this fauna is indicated by the radiocarbon date $(8,490 \pm 100$ years BP (Gd-5123)). The lowering of the ground water level in the Boreal Phase as well as overgrowing and filling with sediments were the main factors responsible for the transformation of the lake into a peat-bog. The fauna with a dominance of species typical for the temporary water bodies (Planorbis planorbis (L.), Pisidium obtusale (Lam.)) corresponds with these processes (Fig. 5). Similar schemes of lake 
evolution in Northern Poland based on the results of palaeographical, palynological as well as malacological analysis were described by several authors (STARKEL 1977, S. W. AlEXANDrOWICZ 1980, 1988, 1989, 1991, 1995, PAWLIKOWSKI et al. 1982,

\section{REFERENCES}

AleXANDROWICZ S. W. 1980. Zespoły malakofauny w kredach jeziornych Ziemi Lubuskiej. Kreda jeziorna i gytie 2: 24-32.

AleXANDrowicz S. W. 1987. Analiza malakologiczna w badaniach osadów czwartorzędowych. Zesz. Nauk. AGH, Kwart. Geologia 12: 3-240.

AleXANDrowicz S. W. 1988. Molluscan assemblages of the lacustrine sediments in the ancient melt-lake Orle. Folia Quatern. 58: 59-67.

ALEXANDROWICZ S. W. 1989. Zespoły mięczaków w późnoczwartorzędowych osadach jeziornych północnej Polski. Stud. Mat. Ocean. 56: 267-276.

ALEXANDROWICZ S. W. 1991. The malacofauna of the holocene lacustrine sediments of Dąbki near Darłowo. Przegl. Archeol. 28: 19-24.

AlEXANDROWICZ S. W. 1995. Malacofauna of the Holocene sediments in Grabowo near Koszalin (Pomerania, North Poland). Quest. Geogr. 4: 13-20.

AleXANDrowicz S. W. 1999. Tanatocenozy muszlowe w rzecznym środowisku sedymentacyjnym - metody badań i interpretacji. Zesz. Nauk. AGH, Kwart. Geologia 25: 211-295.

Alexandrowicz S. W., AleXandrowicz W. P. 1995a. Quaternary molluscan assemblages of the Polish Carpathians. Stud. Geomorph. Carpath.-Balc. 29: 41-54.

Alexandrowicz S. W., Alexandrowicz W. P. 1995b. Molluscan fauna of the Upper Vistulian and Early Holocene sediments of South Poland. Bull. Perygl. 34: 5-19.

Alexandrowicz S. W., Cichosz-KosteckA A., Florek E., FLOREK W., ORŁOWSKI A., RĄCZKOWSKI W., ZACHOWICZ J. 1989. Ewolucja doliny Słupii w późnym vistulianie i holocenie. Zesz. Nauk. AGH, Kwart. Geologia 15: 5-218.

AlEXANDROWICZ S. W., NOWACZYK B. 1982. Late Glacial and Holocene lake sediments at Pomorsko near Sulechów. Quest. Geogr. 8: 5-17.

AleXANDrowicz S. W., TCHÓRZEWSKA D. 1981. Kreda jeziorna w osadach czwartorzęowych Środkowego Pomorza. Zesz. Nauk. AGH, Kwart. Geologia 7: 59-71.

ALEXANDROWICZ W. P. 1999. Evolution of the malacological assemblages in North Poland during the Late Glacial and Early Holocene. Folia Quatern. 70: 39-69.
RALSKA-JASIEWICZOWA \& STARKEL 1988, W. P. ALEXANDROWICZ 1999, WOJCIECHOWSKI 2000 and others).

AlEXANDROWICZ W. P., SAN'KO A. F. 1997. Malacofauna and calcareous deposits in the Ptich Valley (Minsk Upland, Belarus). Folia Quatern. 68: 203-211.

BRODNIEWICZ I. 1979. Analiza faunistyczna późnoglacjalnych osadów słodkowodnych z klifu nadbrzeżnego koło Ustki. Wyd. UAM, Geologia 9: 3-27.

Dyduch-FAlniowska A., Piechocki A. 1993. Mięczaki (Mollusca), Małże (Bivalvia). Fauna Słodkowodna Polski 7a, PWN, Warszawa.

Limondine N. 1992. Biogeographie de Vertiginidae (Mollusca-Gastropoda) europeens: relations avec la derniere deglaciation. C.R. Acad. Sci. 315: 1281-1287.

LO EK V. 1964. Quartärmollusken der Tschechoslovakei. Rozpr. Ustr. Ust. Geol. 31: 3-374.

MATUSZEWSKI A. 1979. Dokumentacja geologiczna złoża kruszywa naturalnego i kredy jeziornej „Skowarcz-Pszczółki”. Archiwum Zakładu Gdańskiego Przedsiębiorstwa Geologicznego w Warszawie.

PAWLIKOWSKI M., RALSKa-JASIEWICZOWA M., SCHÖNBORN W., STUPNiCKA E., SEROCZYŃSKA K. 1982. Woryty near Gietrzwałd, Olsztyn Lake District, NE Poland - vegetational history and lake development during the last 12000 years. Acta Paleobot. 22: 85-116.

PIECHOCKI A. 1979. Mięczaki (Mollusca), Ślimaki (Gastropoda). Fauna Słodkowodna Polski 7, PWN, Warszawa.

RALSKA-JASIEWICZOWA M., STARKEL L. 1988. Record of the hydrological changes during the Holocene in the lake, mire and fluvial deposits of Poland. Folia Quatern. 57: 91-127.

RIEDEL A. 1988. Ślimaki lądowe (Gastropoda terrestria). Katalog fauny Polski 36, PWN, Warszawa.

STARKEL L. 1977. Paleogeografia holocenu. PWN, Warszawa.

STEENBERG C. M. 1917. Furesöens molluskenfauna. Königl. Dansk. Viden. Selsk. Skrift., Nat.-Mat. 8: 78-200.

WOJCIECHOWSKI A. 2000. Zmiany paleohydrologiczne w środkowej Wielkopolsce w ciągu ostatnich 12000 lat w świetle badań osadów jeziornych rynny Kórnicko-Zaniemyskiej. Seria Geografia, UAM, Poznań 63: 5-236.

Received: September 2nd, 2002 Accepted: October 15th, 2002 